\title{
Textiles and the making of sacred space
}

Timothy Carroll

Abstract:

This paper develops a perspective on fabric and its use in religious settings working from a comparative survey of critical literature arising, primarily, from anthropological writings on cloth and clothing in conjunction with insights gained from ethnographic research among Eastern Orthodox Christians. While the character of Orthodox Christianity, and the broad nature of comparative religion, shape how the argument is presented, the primary focus of the paper is not on the religious contexts, but rather the particular items of fabric in use, and, more generally, the exact qualities of fabric that allow for its use in such diverse contexts. Rather than taking an argument of historical specificity, the paper is grounded in a material culture approach to fabric, suggesting that a cross-cultural appraisal of fabric that spans different historical periods allows critical insight into the modes of operation within human experience. The central argument of the paper is that, because of the material qualities inherent in fabric, it can be used in such a manner as to make present the sacred.

Key words: fabric, lived practice, religion, Orthodox Christianity, sacred

Introduction:

Religions, even the most anti-materialistic ones, as Webb Keane and David Morgan have shown, ${ }^{1}$ rely upon material in order to achieve the experience of the sacred they pursue. This paper looks closely at one such material that is often employed in religious settings in order to unpack the possible roles this material plays within society and religious experience. Drawing on a broad, though by no means comprehensive, anthropological literature review of fabric, the author's own fieldwork amongst Orthodox Christians is used to exemplify and add analytical detail to the emergent trends seen in wider literature on fabric. 
This research grew out of a project, funded by the Pasold Research Fund, interested in the historical development of the fabrics used in Eastern Orthodox Christian religious practice, particularly in the Greek Orthodox monastery of Vatopedi. This paper, however, does not follow a historical paradigm, and this is for two reasons. The first is a pragmatic one: During the period of time that I was at Vatopedi, the monastery was experiencing a series of unexpected events. This included on-going legal disputes with the Greek government as well as a string of bishops visiting the brotherhood—two very different types of distractions, but each with its own demands on the monastery's senior leadership. As such, while I had been granted access following the introduction from a monk trained in Vatopedi whom I had met during fieldwork in London, once there I was not able to access the archives and collections as initially indicated. Coincidently, there has been a recent growth in literature, even since conducting this research, which offers various historical insights into Orthodox fabric, and particularly vestments. ${ }^{2}$ In light of the restrictions placed on my research I redirected my attention to the daily happenings of the monastery. The monks warmly received me, and the abbot gave me his blessing to conduct what research I needed in order that my time there might be productive; and it was productive.

[nsert Figure 1 roughly here — 'Figure 1: Monastery of Vatopedi and surrounding farm and fishing village. Photo by author.']

In total, I spent roughly seven weeks working alongside the monks, joining in the monastery's services and daily life, and speaking with the monks and pilgrims. This led to the second—and more important—reason for privileging an approach other than one of historical development. During my time at the monastery, and throughout the three years of ethnographic research amongst Orthodox Christian communities in London, I 
became increasingly convinced that an historical perspective would offer little insight into the actual use of the items of fabric in question. Historical narratives of a particular item's trajectory, or the development of a particular item of vesture, were not used to justify use or articulate the importance or meaning of any symbolic object or gesture. In fact, when historical accounts were known and offered, they almost always had more than one account and would be deployed as a way to think about religious practice- the practices themselves were never in need of justification. This fits with other trends in Eastern and Oriental Christian pedagogical practice: particularly in terms of the importance of allegorical interpretations and the use of parables. These historical accounts are true, not because of the historical fact, but because of their didactic application to the present circumstances. When various accounts are taken together, they become, from a historical perspective, even more problematic.

For example, during one early morning service at Vatopedi in late August 2011, a velvet slipper was presented by the priest, and arranged on a table toward the front of the main church. The monastery holds several hundred relics, and as such it is quite common for relics to be brought out during morning services. Following a practice that became quite familiar to me as the days passed, the monks and pilgrims filed forward to venerate this cloth shoe- a relic of St Athanasius of Constantinople. Hearing the name 'Athanasius', some pilgrims thought - I found out later, after the service - that it was St Athanasius the Great (d. 373) of Alexandria. They were corrected by some of the monks, and told that Athanasius was Patriarch of Constantinople from 1450 to $1453^{3}$; later in life he went to minister in Ukraine. Even after being corrected, pilgrims wondered at how well the shoe was preserved. I asked one of the older monks about this, as the velvet was in such a state it could not have been more than ten years old. The monk confirmed my suspicion. Like St Spyridon of Trimythus (c. 270 - 348), whose woven sandals need to be 
replaced yearly because he is so active in his aid of people about the city of Corfu ${ }^{4}$, St Athanasius' velvet slippers are routinely changed. The miracle accounts, and the sanctity of the bodies of these saints, allow the woven and fabric shoes to circulate as relics, extending the biography of the saints well past death both spatially and temporally. This slipper I saw at Vatopedi had been sent to the monastery recently as a gift.

On one hand it can be seen that the historical context of the slipper adds a depth of understanding and opens up a series of interesting questions in its own right. It speaks of the circulation of fabric relics, the active production of relics, and a practice of clothing the dead. The list could go on, and an interested reader is encouraged to look into St Athanasius, as his biography over the last few hundred years is an interesting one. None of this history mattered, however, to the pilgrims and monks that morning in Vatopedi. Had the slipper been that of St Athanasius the Great, or had it been one worn during the life of St Athanasius rather than being fitted to his body recently-either way, the men there that morning would have nonetheless venerated it. Those whom were corrected showed no regret at having venerated a different saint, and while one young man seemed saddened to not have been able to venerate Athanasius the Great (because of a keen affection he had for this saint), he was nonetheless pleased to learn about a different Athanasius. Anticipating the apparent question about venerating the 'wrong' Athanasius, one monk joked, saying: 'Don't worry, they're friends, he'll let him know.' Had everyone, as only some had, known that it was a shoe only recently made and worn by the dead saint, they would still have venerated it—kissing it in honour of the sainted dead bishop.

In practical terms, the history of the object, even the history of the practice, matters little when it comes to quotidian practice. Yes theologians worry about these issues, and there is serious historical research and documentation leading up to the official recognition of 
a saint. But this official and historical process of canonization is done in response to preexisting vernacular, or 'grass-roots' devotion. The as-of-yet un-recognised saint (often a beloved spiritual mother or father) is often locally venerated long before the synod (the Church's governing body) meets to officially recognise a 'new' saint. The canonisation of a new saint often has little real effect on vernacular practice as, by the time of such a pronouncement, there is already a visual (iconographic) tradition as well as pilgrimage to the grave, miracle accounts, and a growing popular devotion. In terms of how Orthodox Christians engage these icons and relics the fine details of historicity are of little to no concern. The process by which a locally held saint is attested to and, eventually, gains wider (and eventually official) recognition is certainly one that pays attention to the historical veracity of the saintly life. ${ }^{5}$ But in the day-to-day practice of the saints—-that is, their veneration and remembrance - the hagiographical narratives take on a certain nonhistorical present tense. As I have argued elsewhere ${ }^{6}$, the Orthodox Christian practice of the saints collapses the chronological aspect of time; drawing on the anthropologist Alfred Gell's use of Husserl's phenomenology of time, wherein past moments are experienced in the present as 'retentions' and future moments are experienced in the present as 'protentions', I argue there that icons and relics become 'material retentions' allowing contemporary Orthodox Christians to participate in the same embodied act of veneration as previous generations. In this way, the 'temporal horizons' - that is, the outer edges, back and forward, of the 'present' - are expanded so as to encompass the entire Orthodox community (past and anticipated future) in a present, participatory, 'now'. Building on this argument, this paper does not ask the historical question: 'How did fabric come to help make the holy?', but rather asks 'How is fabric able to make the holy?'. 
As such, in order to frame the argument as one about fabric, as a material, and how it can operate in human society, this paper moves through a review of literature with very little overt respect of time and location. I am not interested, for example, in the influences of American Catholicism on American Quakerism, nor in how these traditions are related to that of Eastern Orthodox Christianity—rather I am interested in how each is able to engage textiles in meaningful ways. This large-scale comparison - focusing little on the historical and cultural contexts - of how fabric is used socially allows for an enriched view of the material and its possibilities as a social thing. This view, I argue, can then be applied to help illuminate specific social phenomena; here exemplified through case studies drawn from the Eastern Orthodox context.

As will be discussed in greater detail below, fabric is often used to help make sacred space, or heighten the sacrosanct quality of a ritual setting. Whereas one might suppose it is the lavish quality, the expensive sourcing or some other form of rarity that affords the fabric its special role- this appears not to be the case. Expensive fabrics are often used, but this is attributed to the importance of beautifying the space of worship (as it is seen as a representation of heaven) or to the act of self-sacrifice (in affording the very best) in offering to the Church such exquisite fabrics. These, however, are all secondary to the ability of fabric to help make sacred space. The argument here sustained is that it is rather the simple material qualities of fabric: that it is ephemeral; that it can be manipulated; that it folds and flutters- that allow it to fulfil such a potent function within the making of the holy.

\section{Toward fabric as a five-dimensional thing}

This section works through a significant overview of the anthropological literature concerning fabric in order to provide a context within which to understand the claims 
made in this paper concerning the positional efficacy of fabric and the experiences of the divine which fabric facilitates. The literature here discussed is in no way comprehensive of the vast literature of fabric and related phenomena, such as dress; rather it highlights general understandings (such as social demarcation) and focuses more to the point of the paper concerning the material - and immaterial - qualities of fabric in religious engagement. It is the argument here laid out that fabric must be understood as a fivedimensional thing.

[nsert Figure 2 roughly here — 'Figure 2: An epigonation (item of priestly vesture worn over the right thigh) hung as decoration. This could be productively analysed as twodimensional motif, showing an icon of Christ's resurrection looked on by the Four Beasts representing the Gospels. Photo by author.']

The section first considers the material aspects of fabric, going beyond the warp and weft (the lengthwise and crosswise threads, respectively), suggesting that the length and width must be understood also in light of the thickness of the fabric as well as the enacted capacity that it (as a three dimensional object) allows through use in gestured time (as a four dimensional object). Put more simply: Let the reader imagine a handkerchief lying on the table in front of them. It has threads running up-and-down, and side-to-side. It has a pattern, too, perchance, and some embroidery - a monogram or a stitched border. This pattern, then, is not simply two-dimensional. A silk handkerchief has a different thickness than one of cotton, and the embroidery adds a further depth, an added thickness that you might pick at unconsciously as you wait for someone at the train station. Now, imagine you see your friend - or lover, your preference - coming off the train. You are waiting at the gates, but want them to see you, so they know which gates to exit toward. You hold the kerchief high and wave it. Here, in this gestured motion, as 
it billows back and forth like a little flag, it manifests a further depth. It is not just a flat pattern, nor is it simply a static object in 3-D, it moves, and in that movement is the fourth dimension: time.

This fourth dimension of use-in-time plays out in social space that, for purposes here, is best broken into two categories roughly along the 'mundane' and 'sacred' boundary. I classify the 'mundane' or 'normative' social negotiations as those around gender, politics, kinship and group solidarity versus individuation. The 'sacred' or 'religious' domain is distinguished from this very broad social category in order to move the discussion toward the specific topic of religious use. Obviously, in many cases, normative social negotiations—-such as gender, politics, kinship and solidarity—are intimately woven within the religious domain. Take, for example, the issues of bijab. However, the somewhat arbitrary distinction, singling out religion from more general sociality, allows us to focus more specifically on those aspects of life, which, even within religious settings, have a particularly strong impact on the person and community. Heightening the emphasis on religion, the article then addresses what will be called the 'sublime negotiations' - these negotiations relate to those situations where fabric is used to transform, transcend and spiritualise in particularly intense ways. ${ }^{7}$ From this follows the discussion of the fifth dimension of fabric, a pneumatic quality that cannot be described using the analytical categories of material and visual culture.

\section{Material Negotiations}

In her work on tivaivai (a quilted Cook Island blanket), anthropologist Susanne Küchler argues that it is the material resonances themselves that account for the indexical and iconic properties around fabric. ${ }^{8}$ For Küchler, these relational properties are not simply ascribed to the cloth things, but are actually an 'intrinsic part' of the material. ${ }^{9}$ While the 
quilted blankets Küchler is speaking of could be seen as flat images (and are at times displayed as such ${ }^{10}$, the social contexts of the production, circulation, and display of these objects demonstrate that they have much more depth. The layering of small pieces upon each other during the quilting process produces not only a discernable thickness, but also suggests power and abundance. ${ }^{11}$ Once perfumed and coloured, the pliability further allows the item to be wrapped and folded, actions which take the metaphors of sociality and concretise them within a physical and performative space of storage, gift exchange, kinship and funerary ritual. ${ }^{12}$

The pliability of fabric allows for the bending of two-dimensional motifs into threedimensional space. As Visa Immonen points out, ${ }^{13}$ this may allow iconological content to be experienced in new and changing ways either by revealing or concealing the possible meanings and relationships that have been invested into the artefact design. Cynthia Becker's discussion of Moroccan Berber dress exemplifies this two-come-threedimensional motivic transformation pointing out that the use of symmetry on the part of Berber women transform the body into a large fertile landscape. ${ }^{14}$ By positioning these motifs either in the eye or the memory, fabric's fluidity enables these associations to be made on multiple resonances. Recognising this sort of phenomena, the Roman Catholic Church in North America instructed their ministers, saying that 'the corporal senses [are] the inlets of all holy impressions to the soul'. ${ }^{15}$ The eyes, they continue, are the most powerful. It is through the eyes that fabric is most often sensed, but the tactile expression of fabric is likewise powerful to those who wear or otherwise touch an artefact. The versatility of fabric's materiality allows a wide variety of uses, each with various practical and symbolic importances. Take, for example, a sari's palu - or train which hangs loose off the shoulder; it is employed alternatively as hot pad while cooking, a third hand upon which a child may hold, or an object of play and flirtation. ${ }^{16}$ The 
pliability, softness, insulation and countless other material qualities that may change depending on the sari in question (such as colour, texture, fall and the means in which it plays with light) afford this simple, two dimensional piece of cloth a vitality, extending the person beyond their own skin. This is the potency of fabric in action, when the threedimensional object is placed in motion (or, even stasis) through time, enacting it as a four-dimensional thing.

\section{Normative social negotiations}

As an enacted thing, fabric is relational; it is situated in a nexus of those using and being affected by its use. Fabric is thereby also social. As fabric is employed in social negotiation, it may denote and bring into being a multitude of possible effects. Several anthropologists, sociologists, and social historians have written concerning the process by which people dress as a means to express who they are, or build confidence, or otherwise prepare for the social obligations of the day. ${ }^{17}$ Particularly as this article pertains to fabric's role in making space, it is worth highlighting that this quality of fabric to play a role in social relations applies not only to the person, but to the built environment, as well. The formal relations between bodies and architectural form have been a recurrent theme in literature concerning the built environment since, at least, Vitruvius' De Architectura (17 BCE). ${ }^{18}$ The social and affective relations between bodies and the built environment - especially the home, have also been widely noted, ${ }^{19}$ and this is true in religious contexts as well. ${ }^{20}$ In her work on Batammaliba (of Togo and Benin) architectural form, Suzanne Preston Blier discusses the similitude between the house and the body, noting that the house, like the body, is dressed in order to undergo periods of initiation. ${ }^{21}$ 'Rich, foreign-made cloths,' she writes, 'are hung over the upper walls of the house to recall those worn over the shoulders of young men and women at the public ceremonies ending the initiatory cycle'. ${ }^{22}$ These same cloths are used to veil both the 
house and the person from society. ${ }^{23}$ In each case, fabric is used to help affect the initiatory transformation - in both place and person. The Batammaliba house can also be seen, however, to be dressed in its material design, as the outer walls are given an ornate cicatrisation (incised cutting into the surface) done in the same pattern as that given to young women, such that ' $[\mathrm{t}]$ he undulating form of the molding suggests both traditional woman's parure, a long fiber cord wrapped around the hips, and the thin skin belt worn around the waists of men' ${ }^{24}$ The architectural motif, modelled on local textiles, seen here is reminiscent of arguments put forward by John Ruskin (1819-1900) - who understood architectural surface (like clothing on a person) to show forth the moral quality of the interior. ${ }^{25}$ The Batammaliba example may also remind us of Gottfried Semper's suggestion that weaving (and knotting) of textiles was the precursor to the architectural form. ${ }^{26}$ While the ceremonial use of cloth, as described by Blier, lends itself to more religious aspects of fabric, discussed below, the cicatrisation - even though it is not textile with warp and weft - suggests that exterior designs of buildings are similar in affective terms to dress. ${ }^{27}$ These routine aspects of dress build toward normative sociality, or what is here called the 'socionormative'. At this level, fabric is seen to facilitate social interaction; it is a material means by which people are able to negotiate value-laden sociocultural behaviour.

A number of examples exist showing solidarity to be built through similar means of dress. By wrapping the body, fabric is able to clothe the body in recognisable iconological ${ }^{28}$ associations. This can be seen among the African diasoporas, where group solidarity as well as gendered and/or power dynamics are demarcated through the use and type of fabric. ${ }^{29}$ Similarly, Linda Arthur has edited two volumes, ${ }^{30}$ each of which demonstrates a strong link between the public individual and their identification as one of an age, gender, caste, ethnicity or religion. ${ }^{31}$ Such display may be imposed explicitly, 
such as in the case of uniforms, ${ }^{32}$ or through cultural planning and remembrance. ${ }^{33}$

Solidarity is likewise enacted differently in relation to time depending on when and how fabric is employed. The public display of fabric may itself be an evangelical tool, ${ }^{34}$ where the wearing of monumental fabric is credited with the potency to communicate the unity and essence of a given community. Afe Adogame, working amongst the African diaspora in Europe, places a different emphasis on this unity-through-fabric, as social rank is expressly communicated through the wardrobe of the Celestial Church of Christ (CCC) faithful. ${ }^{35}$ Here, the solidarity and functionality of the person are simultaneously announced, allowing easy navigation in each religious setting even if one has come from a different congregation, elsewhere in the diaspora. In ambiguous spaces, however, individuals may dress themselves in ways so as to appear similarly ambiguous and unremarkable. Elisha Renne, in her discussion of the garments worn by the Cherubim and Seraphim Church (CSC) diaspora, brings to the fore the rich cosmological connotations understood to be inherent in the design and material of the clothing; but she points out that these items are increasingly put on only upon arriving at the 'house' (what might elsewhere be called a church edifice) for the service. ${ }^{36}$

\section{Religious negotiation}

The delay Renne notices, wherein CSC congregants wait until arriving at the house to don religious clothing is strikingly similar to a practice I observed during my fieldwork based in London. From 2009 to 2012, I conducted ethnographic, participatory fieldwork within a small Orthodox Christian parish in east London. I participated in both religious and social aspects of the community, as well as gathering personal histories of many of the parishioners. As part of my attention to how religious practice within the parish related to wider activities within the city, I routinely accompanied a young woman, 
named Joanna, who was in her early twenties, on her way to and from services. Dressed, most often, in flowing skirts and a warm duffle coat, Joanna took the National Rail from a suburban station into London Liverpool Street Station. Rising up the escalator to the ground floor, she would cross the small plaza, past the commemoration of the Kindertransport, and weave her way through the side streets to the St Æthelwald's parish church. At a very close distance to the door, or even on the church doorstep, Joanna would pull from her leather satchel a large scarf. She owned a number of scarves: each large, in various subdued natural hues or black—save the one she wore for Pascha (the Feast of the Resurrection), which was white. Joanna waited until the doorstep to veil, taking the scarf, placing it over her head, and wrapping it around her neck - tucking the ends into her coat. Veiling was something she chose to do herself. About half the women in the parish did likewise, and in each case they waited until they were almost to or inside of the building before veiling.

When asked about this, Joanna, almost hesitant to put it into words; she said she was afraid to be mistaken as a Muslim. She spoke of an Orthodox nun elsewhere in England who, being dressed in a traditional monastic habit, was mistaken for a woman in chador. The possibility of misinterpretation, the possibility that one's life lived for Christ might be mistaken as one lived for a different religious creed, produced an anxiety for a number of the women of St Æthelwald's who chose to veil. The problem, as Joanna expressed it, was that most people traveling with her on the public transport would not know to see a woman in veil and see it as evidence of Christianity. As such, it was better to travel as 'nothing', as it were, rather than the false positive of a different religious conviction.

The tension expressed by Joanna speaks to the artificiality of a distinction between religious and non-religious domains of life. The religious negotiations of her personal 
devotional choice to veil is at the same time bound within a wider context of the multireligious city scape through which she moves. This is itself interesting, and should be seen with reference to Simon Harrison's work on identity. ${ }^{37}$ Harrison outlines various ways in which minority groups suffer infringement, even the violation of personhood, through the appropriation of cultural forms on the part of hegemonic, majority groups. What is interesting here is that while no active misappropriation is taking place (i.e. Muslims in London have not chosen to veil in order to crowd out Orthodox Christian expression in the public sphere), the Orthodox Christian community is forced into silence, made invisible by desire to avoid misidentification. The fault lays not, my informants feel, with the Muslims who veil, but with the wider British audience who choose to identify veiling as a Muslim practice.

Joanna's preference to avoid misidentification is similar to Renne's observation concerning the ambiguity CSC members seek to achieve when moving through ambiguous space. In both cases a clear preference to dress in religious adornment is negotiated in response to wider cultural expectations - that is, a tension arises between the religious domain and the socionormative domain.

Anna-Katharina Höpflinger, in a brief discussion of Joan of Arc, highlights clothing and religion as each being 'complex communication systems that interact in multiple ways'. ${ }^{38}$ This is certainly the case, even in homogenous religious communities, and even more so in areas of diverse mixing influences; but Höpflinger's emphasis on communication should be tempered in light of arguments put forward by Webb Keane and David Morgan suggesting that materiality may constitute, rather than simply communicate, sensations particular to a sense of self and religious experience. ${ }^{39}$ Beth Graybill and Linda Arthur's discussion of Mennonite dress further highlights the issue of complexity, as 
clothing itself becomes synechdotal to the entire socio-religious order as means of control $^{40}$ — similar, in some ways, to what can be seen across Europe regarding the hijab. ${ }^{41}$ This expands the discussion of patriarchal control of women, taking into account, instead, a complete network of control over women, their clothes, their men and the ministers. As is the case in many socially conservative groups, Graybill and Arthur see the codification of outmoded forms of dress to serve as a means of symbolic separation when physical means become strained.

In many ways, the Quaker bonnet was similarly a means of separation and control through arcane modes of fabric use. Amongst the Society of Friends, however, the iconic bonnet was lost roughly by the time of the American Civil War. While the Society moved on to later (i.e. more up to date) modes of dress, narrowing the margin of space between themselves and wider American Protestant circles, the wider American popular culture continued to imagine the Friends' bonnet as integral to the Quaker innocence and preservation. ${ }^{42}$ The imagined innocence took on an illicit and (ergo) alluring connotation, changing the home-grown purity of seclusion into the enchanting fantasy of disclosure. In each of these cases, pieces of fabric, as objects, contain within themselves a correlation to the social contexts in which they exist. As that context changes, so too must the fabric; and, just as the social imagination of the Quaker bonnet diverged from Quaker practice and became productive in its own way within the broader American popular imagination, so too can a change in fabric help facilitate a change in context.

Roughly contemporary to the sexual enchantment of the Quaker bonnet, the Roman Catholic Church pursued a course of re-enchantment, changing the mood of American pietism from lay devotion to sacramental worship. For the faithful Catholic, concealment of the holy objects (including the body of the clergy) beneath layers of European brocade 
distanced the congregation from the mystical, transubstantial focus of devotion-a move that was supposed to make it, consequently, more revered and honoured. The use of rich fabric was expressly encouraged to ensure 'regard and veneration for the mysteries sublime and tremendous, ${ }^{43}$ A century later, when the Roman Church underwent the liturgical reforms of the Second Vatican Council, a new emphasis was placed on fabrics once again. The emphasis of Vatican II, however, was not the sublime and tremendous. Rather, it was the local and personal. The Vatican II reforms identified fabric as one of the means of making the holy mass 'enculturated', that is to say local and indigenous. This reinterpretation afforded local textiles a place in the ecclesiastic economy. Examples of the Ghanaian ${ }^{44}$ and Nigerian ${ }^{45}$ Catholic diocese both attest to the renewed interest in local production of traditional fabrics, reimagined for liturgical purposes as stoles and other clerical and decorative functions. Malika Kraamer notes that this shift toward liturgical uses for the traditional fabric carried with it an invention of new motifs to express the ideology of the new contextual space.

The use of fabric as a place for emergent ideologically charged motifs is not unique to Kraamer's Ghanaian Catholics. Laura Cochrane discusses at length the process by which Senegalese weavers practice their craft and religion simultaneously. ${ }^{46}$ She explains, This relationship [between religion and weaving] is indexical: weaving does not exist simply to refer to religious beliefs. Instead, beliefs, material processes of weaving, and the discourse surrounding weaving are each constantly present. ${ }^{47}$

Here, design 'has a spiritual interpretation, only evident when understood through the lens of believers' explanations'. ${ }^{48}$ These are dynamic interpretations, subject to change as the index is affected by its referent. The weavers in turn become religious experts themselves as they turn their 'inspiration into influence by discussing their work in the public realm. Their personal interpretations of their craft become new ways to practice faith'. ${ }^{49}$ Playing in the flexibility that their craft affords them, these weavers, like their 
Ghanaian counterparts, find new ways of religious devotion within the textiles themselves.

It is here, in the space of profound religious devotion that, what I call, the 'sublime negotiation' takes place. Whether this is unscripted, such as in the Senegalese case, or highly scripted, as with Catholic sacramental devotion, the negotiation with the sublime sees the great and the awe-full play in tactile and visual sociality.

\section{Sublime negotiation}

There are three primary modes of sublime negotiation. The first, alluded to in the previous section, is a direct connection between the mundane fabric as revealed or inspired testimony of the supramundane (that is, situated above worldly matters). The second mode is when there is a connotative, or implicit association between the substance of the mundane material and the supramundane, cosmological truth. The last is manifest as an internalisation of the sacred (i.e. the religious improvement of the subject) by means of the mundane. These should not be seen as distinct categories, but rather useful analytical emphases.

[Insert Figure 3 roughly here — 'Figure 3: While reciting the creed, the priest flutters the aër (veil) over the bread and wine in preparation for the consecration of the Eucharist. Photo by author.'

The Senegalese weaver performs two negotiations as she speaks of her weaving in the public forum. To view her actions only on the socioreligious plane, denies the role in which this act of public reflection and interpretation around the fabric is also an act of devotion through the fabric. By finding new ways of religious expression, she is 
relearning her faith in and through the inspiration of the textile. By contrast, the fabric used by the CSC is not left to individual interpretation, but nonetheless is the locus of spiritual encounter. For the CSC, the costumes that are worn are the direct product of revelation. ${ }^{50}$ Visionary leaders have, through dream, witnessed the angelic choirs and the earthly services are done after this model. This applies specifically to the manner of dress, whereby the ranks of the faithful are dressed even as the ranks of angels. Fabric, then, becomes the manifestation of divine revelation — to see the clothing is to see heaven.

Not unlike this, is the use of white in the CCC. The faithful dress, completely, in white garments — an outward projection of their inner holiness. ${ }^{51}$ It is only once someone is entirely dressed in the white robes that they are allowed into the sanctuary. The fabric and its proximity to the body, reveal to the eyes what is already true in the spirit. The revelation of inner purity made through the fabric sets the congregation apart, in a separate space, filled only with purity.

In the CCC, it is the accidental property of the fabric (e.g. its whiteness) that allows it to act as the externalising force of revelation. In this example, the connotative association (mode two) between white and purity enables the revealed testimony (mode one) showing the congregation to be holy. The fabric, by shrouding the CCC members, is able to make visible the 'true', divine, reality of the congregation.

Polynesian ethnography and historical testimony allow for a similar, if not more powerful, understanding of fabric and its connotative ability to presence the sacred or other-worldly. In Susanne Küchler's work on the Cook Islands, she discusses how the practice of wrapping in layers of fabric in the Cook Islands plays with the manipulation 
of the material in order to demonstrate the power of the god to'o and the chieftains (and later the missionaries) over death and the ability to give in abundance. ${ }^{52}$ Likewise, Steven Hooper notes how Cook Island staff gods—and similar long, carved to'o deity images from the Society Islands—are wrapped in layers of barkcloth in order to contain the powerful mana (life force) within the object. ${ }^{53}$ Serge Tcherkezoff, in his work on early Polynesian colonial encounters, likens the amount of clothing worn by chiefs and gods in Polynesia to the cosmological gravity located in their person. ${ }^{54}$ The ritual taking off and putting on of fabric connotes the ability to control goods. ${ }^{55}$ While this is in part economic, it is also much broader: it is the gods who can provide this wellbeing, and chiefs - as they gain the power to control such distribution - begin the process of becoming otherworldly. The bending of (two dimensional) space around their (three dimensional) person offers at once an encasing both protective and restraining and makes visual play with the resources both seen and unseen.

The same physical action, of encasing within fabric may also have internalising affect. Examples of the third mode of negotiating the sublime make greater emphasis of the individual's position within the relationship with the divine. For Conservative Jewish women who have taken on the tallit (prayer shawl)—something traditionally only required of men-, the experience is understood as the creation of a space of calm and prayer: a place wherein they may meet God in a tactile way, being wrapped in that 'moment' and 'space. ${ }^{56}$ This quality of somatic perception of God is reminiscent of the American Catholic stance quoted above. As Haas showed, the Catholic understanding of material is that corporal impressions are the means to engaging and impacting the soul. ${ }^{57}$ These are internalising, transcendent experiences necessitating the engagement with the fabric, employing its natural abilities to pull the individual into another domain of engagement. Cordelia Warr relates an account of a Catholic monk who dies having had 
his cuculla (monastic hood) removed. ${ }^{58} \mathrm{He}$ is refused entry into Heaven as he was dressed for work (in a simple cowl) rather than rest (in the cuculla), and thus could not enter into Heaven, which is a place of rest. The account, from the Dialogus Miraculorum, instructs the Catholic monastic communities that these items of fabric are not simply for terrestrial access to God, but rather continue on, playing their part in making the reposed soul worthy of entering into Paradise. The cuculla is given multiple meanings, but there the message is clear: spiritual, eternal preparation is a material process, one in which fabric plays an integral role.

\section{Substance of the immaterial}

This paper argues that investigating fabric as a two dimensional textile short-changes the ways in which fabric is enacted in society. In addition to the warp and weft, fabric is discussed as a three dimensional artefact, enacted in the fourth dimension of time. I have addressed this topic with little reference to historical chronology in order to highlight the qualities of fabric as a material and its ability to become enacted, in time and space, in particularly important - and often overlooked - ways. After examining some of the negotiations wherein fabric is enacted, this section now arrives at the phenomenal ability of fabric to transport people into different places. As one Jewish women, named Sue, whom Emmett interviewed, explained:

The first time I put tallit on felt significant to me. In a way that's hard to put into words. I felt I was doing something to increase my spiritual depth. ... Donning tallit puts you in a different space, in a space that makes it easier to connect to the prayers, in a way that's very hard to understand..$^{59}$

Why and how does fabric enable this kind of spiritual transportation? Tallit is not something casually put on; rather it is a responsibility that the women of Sue's synagogue considered carefully before voting to accept this change to traditional Judaism, which had reserved tallit (and the rule of prayer associated with it) to adult men. Emmett is 
interested primarily in the phenomenon of reinventing traditional Judaism, changing it to keep it alive, and as such never pursues what it is that allows this experience of the divine. The argument here sustained suggests that the answer may be found by looking beyond the four dimensions already discussed. Arising out of the materiality, there appears to be an immaterial affordance of fabric that allows textiles to act in supramundane situations, creating the place for the holy.

In this argument arises the sense of relational affect. In the case study arising from research in Vatopedi that is discussed below, concepts of the person will be addressed, leading to an understanding of the Orthodox person as permeable and processual. What is seen here is the role of material, specifically fabric - and akin to it the built environment, within the affective becoming of people as subjects and Orthodox. As writers in affect theory quickly point out, the body itself is in a state of 'perpetual becoming ${ }^{60}$ in relation to things, people, emotions, and so forth. The continual 'inbetweenity' of the body, as it is affected in on-going forms of contact - in what Gregg and Seigworth call 'bloom-spaces', ${ }^{61}$ is a quality, however, of not only the body, but of the other materials within the material ecology as well. What is argued here, in a way similar to Tim Ingold's idea of things being caught up together in the flow of making, ${ }^{62}$ or to Karen Barad's 'intra-action', ${ }^{63}$ is that fabric also offers something of a bloom, facilitating new ways of coming into being. While this movement is intra-active, there is a definite teleological aspect to the action-making — something noticeably lacking from both Ingold's and Barad's models—, and as such 'co-action' is used here.

By way of example of co-action with fabric, while at the Monastery of Vatopedi, a number of the monastic brothers spoke of a synergistic process by which clothing (and other architectonic forms, such as a hermit's cabin) assists in the penitent's sanctification 
and, as a result, is also 'brought up', that is: 'redeemed'. Taken as a sort of material soteriology, the symbiotic relationship between the textile and the faithful uses and restores the breath of life found in material things. In most cases, the immaterial affordances of fabric are, it seems, irrelevant. However in particular cases, the substance of the immaterial becomes essential to how the fabric is enacted within society. In these cases, fabric must be understood as a five-dimensional artefact, being composed of both material and immaterial.

[nsert Figures $4 \& 5$ roughly here — 'Figure 4 and 5: The reliquary holding the largest piece of the Holy Cincture of the Mother of God (left), arranged on a table for veneration (right). Photos by author.']

Take for example the Agia Zone_-or Holy Cincture_-of the Mother of God. The Holy Great Monastery of Vatopedi, the largest of the monasteries on the Greek peninsula of Mt Athos, holds in its great collection the Agia Zone. According to local account, the cincture is a camelhair belt woven by the Virgin Mary—-the Theotokos, or God-bearer, as she is known in Orthodox Christianity_while still a young girl. After wearing it her whole life, she left it to the Church upon her repose, and - while she was taken up into heaven - her cincture has been cared for through the centuries: first by her waiting maids passed down in their family, then by the Byzantine imperial courts, and then by Vatopedi. Each evening the Agia Zone is brought out along with four other relics for pilgrims to venerate. With a daily intake of a hundred to a hundred and fifty pilgrims, there is each evening a sizeable retinue of pilgrims seeking to venerate the relics laid out on tables within the main church.

On one evening in September 2011, I joined a group for an English-language tour of the 
main church and relics. In the group a Spanish father and son were also present. As nominal Catholics they understood generally the concept of relics, but the son expressed confusion as to how they worked, and so the monk guiding the tour explained saying that the human person is both body and soul, and one cannot be considered without the other. Furthermore, they work together, he said, and here he enmeshed his fingers trying to think of the right world. After flexing his interdigitated hands, he finally settled on the English cognate for the Greek word he was thinking: synergy. There is a synergy between the body and soul, he explained, and then glossed it as 'cooperation'. A man or woman leading a holy life, he continued, does something spiritual, but it cannot be spiritual alone. The body must also take part in the ascetical struggle, and as such the body, too, becomes holy. The god-like quality of saints makes their bodies holy objects, because the connection between the body and the soul works a lasting effect on the physical body, something which lasts even past death.

In this way the synergistic coaction of the material and immaterial connect the two extremes as continuations of each other. In fact, the coaction of material is not limited to the physical body. While various body parts, and especially skulls, are often seen as relics, there is no distinction made between these bodily relics and the fibrous cincture. This belt is brought out each evening for the veneration of the pilgrims, and bolts of cotton ribbon are blessed over the relic in order to produce items that may be given to the faithful with which to return home. In a standard taxonomy of relics—-such as comes from the Roman Catholic tradition and is used in Art Historical studies- these would be call 'tertiary relics ${ }^{664}$. As I have written elsewhere, however, there is no indication that Orthodox Christians count them as a different thing. As seen in the above account of St Athanasius' slipper, bones and items of clothes are each treated in the same fashion ${ }^{65}$. Each is considered to be a relic and they are sought in order to secure various miracles. 
Through the ribbons the Panagia Theotokos has healed numerous cases of cancer, brought child to countless barren women, and protected individuals from harm.

In the same way that, for example, the finger of St John the Forerunner is sufficient to presence the entirety of St John, the 'tertiary relic' of blessed cotton ribbon is spoken of as the belt. It becomes a relic of the relic, but in no way is it considered to diminish the potential wonder-working capacity, and it may likewise be venerated as one would the original. The ephemerality of such an object does not hinder the effect they are able to cause, rather the flexible, soft, manipulability of the fabric heightens the effectiveness. Whereas solid relics require boxes or wall mountings, fabric can be wound, tied, folded around a body or into a pocket. Thus the indexical qualities of the material foster a more synergistic coaction of the small, mutable relic with the body.

In the answer the monk gave to the young Catholic in order to explain how relics are made, we have already mentioned the synergy of body and soul. Now we also have two other synergistic relations. The first synergistic cooperation is between holy persons and their external things, producing these as relics. The Agia Zone, for example, is a relic of the Virgin Mary. Though she is (in Orthodox Christianity) understood to have died, no body remained on earth as she was raised on the third day. Her items of clothing, however, she gave to the Church. These have become holy through their association to her holy life. To put it another way, in Orthodox Christianity, things, as well as people, may become holy, if the 'social life' (following Appadurai ${ }^{66}$ ) of those things is a holy one. The next synergistic relation flows from this. Having been made holy through cooperation in the Virgin's ascetic struggle, the belt was made holy. And while the Panagia was materially removed from the world in her person, her belt remained. This, being given to the Church, is used within the liturgical and pilgrimatic ascesis of 
Orthodox faithful. By aligning the energies of the body and soul to the Holy Belt, a synergetic cooperation is understood to function between the sacred materiality of the Virgin's belt and the aspiring (im)materiality of the penitent's soul and body.

At this point, it is reasonable to consider fabric as both material and immaterial; it both covers and masks and - while doing so - reveals. By doing so, it affords spiritual transcendence (or spiritual immanence) by bringing together issues of the material ecology and sensible space in a potent way. The idea that space fosters transformation is not a novel one. Either as bloom-spaces ${ }^{67}$ or affectual geographies ${ }^{68}$ space is an indisputable part of the experience of the self. Nor is it novel to suggest that fabric helps make space. As mentioned above, architectural form is, by some estimations (viz. Ruskin and Semper), intimately connected with notions of fabric. What this article offers, rather, is the insight that fabric - because of its mundane material affordances - is able to make sacred space.

\section{Conclusion}

Fabric is malleable, ephemeral, and permeable. It can be shaped, but - unless additives such as starch are applied - it remains plastic such that even in its stasis there is implied motion. It frays, bobbles, and tears such that even when it does persevere there is a certain boundedness to it. It allows diverse substances to be married into its materiality: additives such as starch, perfume, pigments, and innumerable other such substances can be set within fabric augmenting its material potentials.

[nsert Figure 6 roughly here — 'Figure 6: Wall icon in the inner narthex of Vatopedi's katholikon (the main church) showing Mary, as she is being taken up into heaven, handing off the Agia Zone to the Apostle Thomas as he is being brought from India, both being 
carried by angels. Photo by author.']

Instead of tracing the historical trajectory of fabric relics, such as the Agia Zone, this paper highlights the social uses of fabric in order to open up the space of fabric artefacts. This is done in order to focus more centrally on the material qualities of fabric, and outline the kinds of social and religious impact fabric is able to have because of its inherent material qualities. Such diverse qualities make it an ideal material upon which to attach cascading images of the holy. With the Agia Zone, its intimate life around the body of the Theotokos has produced it as a relic of her. In the separation of Mary from her garments—-when she died and left her belt before being taken to heaven — there is a physical discontinuity produced wherein the discontinuity itself is a relationship of continuity. Fabric's indexical qualities allow for an intimate, sensual, layering and malleable engagement, such that affective spaces of the holy may be made. These spaces about the person and within the built environment allow the person to experience tangible engagement with objects of transformation.

\section{Acknowledgements:}

Research for this paper was funded in part by the Pasold PhD Grant, Pasold Fund and the Paleologos Graduate Scholarship, Greek Orthodox Archdiocese of America. I would also like to thank Susanne Küchler for her helpful guidance in early stages of this paper and the editors of this journal, especially Kaori O'Connor, and two anonymous reviewers. I am most grateful to the monks of Vatepedi and those in London who allowed me to conduct this research amongst them.

\footnotetext{
1 W. Keane, Christian Moderns: Freedom and Fetish in the Mission Encounter (University of California Press, 2007), and, 'The evidence of the senses and the materiality of religion' The Objects of Evidence: Anthropological Approaches to the Production of Knowledge Special Issue of Journal of the Royal Anthropological Institute 14, S1 (2008), pp. S110-S127. D. Morgan, Religion and Material Culture: The
} 
Matter of Belief (London: Routledge, 2010).

${ }^{2}$ K. West, The Garments of Salvation: Orthodox Christian Liturgical Vesture (Yonkers, NY: St

Vladimir's Seminary Press, 2013). W. Woodfin, The Embodied Icon: Liturgical Vestments and

Sacramental Power in Byzantium (Oxford University Press, 2012).

${ }^{3} \mathrm{He}$ abdicated and left the city with the fall of Constantinople to the Ottomans. After some time on Mt Athos, he left to Ukraine.

${ }^{4}$ St Spyridon, too, left Constantinople in 1453, as his relics were taken from the city and given refuge in Corfu.

${ }^{5}$ Interested readers might, for example, consider the debates concerning the veracity of St Peter the Aleut. Elsewhere I have also noted the contested nature of Our Lady of Walsingham as an Orthodox Christian cite of veneration, see T. Carroll, 'An ancient modernity: Icons and the revitalisation of Britain' in T. Jones and L. Matthews-Jones (eds) The Spirit of Things: Material Religion in Modern Britain (Palgrave Macmillan, 2015)..

${ }^{6}$ Carroll, 'An ancient Modernity'.

${ }^{7}$ It is worth noting that 'sublime' is used here not with the necessary obligation of pain or danger, follow Edmund Burke, The Sublime and Beautiful (1757), (eBook, University of Adelaide 2005). Rather, the term here used is keeping much more with the general meaning, 'Belonging to or designating the highest sphere of thought, existence, or human activity; intellectually or spiritually elevated' (OED).

${ }^{8}$ S. Küchler, 'Why are there Quilts in Polynesia', in S. Küchler and D. Miller eds, Clothing as Material Culture (Oxford: Berg, 2005), pp. 175-191.

${ }^{9}$ Ibid., p. 176.

${ }^{10} \mathrm{~S}$. Küchler and A. Eimke, Tivaivai: The Social Fabric of the Cook Islands (London: British Museum Press, 2009).

${ }^{11} \mathrm{~S}$. Küchler, 'The poncho and quilt: material Christianity in the Cook Islands', in C. Colchester ed., Clotbing the Pacific (Oxford: Berg, 2003).

12 Küchler, 'Why are there Quilts in Polynesia'; Küchler and Eimke, Tivaivai.

${ }^{13} \mathrm{~V}$. Immonen, 'Artifacts, iconology, and the visual process: Liturgical objects in Finland and beyond, c. 1350-1550', Material Religion 7, no. 2 (2011), pp. 194-219.

${ }^{14}$ C. Becker, 'Awakening the senses: The aesthetics of Moroccan Berber dress', in D. C. Johnson and H. Bradley Foster eds, Dress Sense: Emotional and Sensory Experiences of the Body and Clothes (Oxford: Berg, 2007), pp. 72-83.

${ }^{15}$ As quoted in K. Haas, The Fabric of Religion: Vestments and devotional Catholicism in nineteenth-century America', Material Religion 3, no. 2 (2007), p. 205.

${ }^{16}$ M. Banerjee and D. Miller, The Sari (Oxford: Berg, 2003).

${ }^{17}$ e.g. K. Medvedev, 'Dress, Hungarian socialism, and resistance' in D. Johnson and H. Foster eds, Dress Sense: Emotional and Sensory Experiences of the Body and Clothes (Oxford: Berg, 2007); L. Norris, Recycling Indian Clotbing: Global Contexts of Reuse and V alue (Indiana University Press, 2010); S. Woodward, 'Looking good, feeling right: aesthetics of the self in D. Miller and S. Küchler eds, Clothing as Material Culture (Oxford: Berg, 2005), pp. 21-40; S. Woodward, Why Women Wear What They Wear (Oxford: Berg, 2007); P. McNeil \& G. Riello, 'The Art and Science of Walking: Gender, Space, and the Fashionable Body in the Long Eighteenth Century' Fashion Theory 9, Is 2 (2005), pp. 175-204; G. Riello, Consumers, Producers and Footwear in the Long Eighteenth Century (Oxford: Oxford University Press, 2006).

${ }^{18}$ V. Buchli, An Anthropology of Architecture (London: Bloomsbury, 2013), p. 137; A. Chatterjee, 'Tectonic into textile: John Ruskin and his obsession with the architectural surface', Textile 7, no. 1 (2009), p. 73.

${ }_{19}$ Bourdieu, The Logic of Practice (Stanford University Press, 1990); Buchli, An Anthropology of Architecture; J. Carsten and S. Hugh-Jones, 'Introduction: About the house-Levi-Strauss and beyond' in J. Carsten and S. Hugh-Jones eds, About the House: Levi-Strauss and Beyond (Cambridge University Press, 1995).

${ }^{20}$ K. L. O'Neill, 'Beyond broken: Affective spaces and the study of American Religion', Journal of the American Academy of Religion 81, no. 4 (2013), pp. 1093-1116. 
${ }^{21}$ S. P. Blier, The Anatomy of Architecture: Ontology and Metaphor in Batammaliba Architectural Expression (University of Chicago Press, 1987).

22 Ibid., pp. 129-130.

${ }^{23}$ Ibid.

${ }^{24}$ Ibid., p. 128.

${ }^{25}$ A. Chatterjee, 'Tectonic into textile: John Ruskin and his obsession with the architectural surface', Textile 7, no. 1 (2009), pp. 68-97.

${ }^{26}$ G. Semper, The Four Elements of Architecture and Other Writings (Cambridge University Press, 1989).

${ }^{27}$ Buchli, An Anthropology of Architecture.

${ }^{28} \mathrm{I}$ am using 'iconological' roughly following Erwin Panofsky who, linking 'iconology' with the interpretation of "symbolical' values', proposes that: 'Iconology, then, is a method of interpretation which arises from synthesis rather than analysis. And as the correct identification of motifs is the prerequisite of their correct iconographical analysis, so is the correct analysis of images, stories and allegories the prerequisite of their iconological interpretation...' In

'Iconography and iconology: An introduction to the study of renaissance art' in Meaning in the Visual Arts (Chicago: Chicago University Press, 1982), pp. 26-54.

29 J. M. Allman, Fashioning Africa: Power and the Politics of Dress (Indiana University Press, 2004); K. T. Hansen, 'From thrift to fashion: Materiality and aesthetics in dress practices in Zambia', in S. Küchler and D. Miller eds, Clothing as Material Culture (Oxford: Berg, 2005), pp. 107-120; A. Trude, 'Pattern, Accumulation, and a Technology of Surface: A Study of Wax Print Cloth Among Ghanaians in London' (Unpublished PhD Thesis, UCL, 2007).

${ }^{30}$ L. Arthur ed., Religion, Dress and the Body (Oxford: Berg, 1999); L. Arthur ed., Undressing Religion: Commitment and Conversion from a Cross-cultural Perspective (Oxford: Berg, 2000).

${ }^{31} \mathrm{C}$. Breward, 'Manliness, modernity and the shaping of male clothing', in J. Entwistle and E. Wilson eds, Body Dressing (Oxford: Berg, 2001), pp. 165-182; D. Davies, 'Gestus manifests habitus: Dress and the Mormon', in W. Keenan ed., Dressed to Impress: Looking the Part (Oxford: Berg, 2001), pp. 123-140; R. Holliday, 'Fashioning the queer self' in J. Entwistle and E. Wilson eds, Body Dressing, (Oxford: Berg, 2001), pp. 215-232; B. Osgerby, Playboys in Paradise: Masculinity, Youth and Leisure-style in Modern America (Oxford: Berg, 2001); Ö. Sandikci and G. Ger, 'Aesthetics, Ethics and Politics of the Turkish Headscarf', in S. Küchler and D. Miller eds, Clothing as Material Culture (Oxford: Berg, 2005), pp. 61-82.

${ }^{32}$ N. Joseph, Uniforms and Nonuniforms: Communication Through Clothing (Greenwood Press, 1986).

${ }^{33}$ T. Akinwumi and E. Renne, 'Commemorative textiles and Anglican Church history in Ondo, Nigeria', Textile 6, no. 2 (2008), pp. 126-145.

34 Ibid.

35 A. Adogame, 'Ranks and robes: Art symbolism and identity in the Celestial Church of Christ in the European diaspora', Material Religion 5, no. 1 (2009), pp. 10-33.

${ }^{36}$ E. Renne, 'Consecrated garments and space in the Cherubim and Seraphim Church diaspora', Material Culture 5, no. 1 (2009), pp. 70-87.

${ }^{37}$ S. Harrison, 'Identity as a scarce resource', Social Anthropology 7, no. 3 (1999), pp. 239-251.

38 A.K. Höpflinger, ' 'She even carried weapons': Clothing, religion and identity the example of Joan of Arc', Material Religion 6, no. 3 (2010), pp. 375.

${ }^{39}$ Keane, Christian Moderns; Keane, 'The evidence of the sences'; Morgan, Religion and Material Culture.

${ }^{40} \mathrm{~B}$. Graybill and L. Arthur, 'The social control of women's bodies in two Mennonite communities', in L. Arthur ed., Religion, Dress and the Body (Oxford: Berg, 1999), pp. 9-30.

${ }^{41}$ M. Brown, 'Multiple meanings of the hijab in contemporary France' in W. Keenan ed., Dressed to Impress: Looking the Part (Oxford: Berg, 2001), pp. 105-122; P. Calefato, The Clothed Body (London: Bloomsbury, 2004).

42 J. L. Connerley, 'Quaker bonnets and the erotic feminine in American popular culture', Material Religion 2, no. 2 (2006), pp. 174-203.

${ }^{43}$ Bishop Francis Kenrick in K. Haas, 'The Fabric of Religion: Vestments and devotional Catholicism in nineteenth-century America', Material Religion 3, no. 2 (2007), pp. 196. 
${ }^{44}$ M. Kraamer, 'Weaving a Biblical text: ewe cloth and Christianity', Material Religion 5, no. 1 (2009), pp. 34-49.

${ }^{45}$ E. Renne, 'Cloth and conversion: Yoruba textiles and ecclesiastical dress', in L. Arthur ed. Undressing Religion (Oxford: Berg, 2000), pp. 7-24.

${ }^{46}$ L. L. Cochrane, 'Religious expression in Senegalese weavers' work', Material Religion 5, no. 2 (2009), pp. 206-223.

${ }^{47}$ Ibid., p. 208.

${ }^{48}$ Ibid., p. 213.

${ }^{49}$ Ibid., p. 220.

${ }^{50}$ E. Renne, 'Consecrated garments and space in the Cherubim and Seraphim Church diaspora', Material Culture 5, no. 1 (2009), pp. 70-87.

51 Adogame, 'Ranks and robes'.

${ }^{52}$ Küchler, 'The poncho and quilt'.

${ }^{53}$ S. Hooper, Pacific Encounters: Art \& Divinity in Polynesia, 1760-1860 (University of Hawaii Press, 2006).

${ }^{54}$ S. Tcherkezoff, 'On cloth, gifts and nudity: Regarding some European misunderstandings during early encounters in Polynesia', in C. Colchester ed., Clotbing the Pacific (Oxford: Berg, 2003), pp. 51-75.

${ }^{55} \mathrm{~N}$. Thomas, 'The case of the misplaced ponchos: Speculations concerning the history of cloth in Polynesia', Journal of Material Culture 4, no. 5 (1999), pp. 5-20.

56 A. Emmett, 'A ritual garment, the Synagogue, and gender questions', Material Religion 3, no. 1 (2007), pp. 76-87.

${ }^{57} \mathrm{~K}$. Haas, 'The Fabric of Religion: Vestments and devotional Catholicism in nineteenth-century America', Material Religion 3, no. 2 (2007), pp. 190-217.

${ }^{58}$ C. Warr, 'Materiality and Immateriality', Material Religion 6, no. 3 (2010), pp. 372-373.

${ }^{59}$ Sue in Emmett, 'A ritual garment', p. 82.

${ }^{60}$ M. Gregg and G. Seigworth, 'Introduction', in Gregg and Seigworth eds, The Affect Theory

Reader (Duke University Press, 2010), p. 3, emphasis original.

${ }^{61}$ Gregg and Seigworth, The Affect Theory Reader.

${ }^{62}$ T. Ingold, 'Materials against materiality', Archaeological Dialogues 14, no. 1 (2007), pp. 1-16.

${ }^{63} \mathrm{~K}$. Barad, Meeting the Universe Halfway: Quantum Physics and the Entanglement of Matter and Meaning. (Duke University Press, 2007).

${ }^{64}$ For example, see: C. Hahn, 'What do reliquaries do for relics?', Numen 57, nos. 3-4 (2010), pp. 284-316; S. Hooper, 'A cross-cultural theory of relics: on understanding religion, bodies, artefacts, images and art', $W$ orld $A r t 4$, no. 2 (2014), pp. 175-207.). The distinction is not particularly helpful in understanding Orthodox Christian use of relics but is a useful analytical term. (For more on this, see T. Carroll, 'Im/material objects: Relics, gestured signs, and the substance of the immaterial' in T. Hutchings and J. McKenzie (eds) Materiality and the Study of Religion: The Stuff of the Sacred. (Routledge, 2016).)

${ }^{65}$ Carroll, 'Im/material objects'.

66 A. Appadurai, The Social Life of Things: Commodities in Cultural Perspective (Cambridge: Cambridge University Press, 1986).

${ }^{67}$ Gregg and Seigworth, Affect Theory Reader.

${ }^{68}$ Y. Navaro-Yashin, The Make-Believe Space: Affective Geography in a Postwar Polity (Duke University Press, 2012); D. P. Tolia-Kelly, 'Affect - an ethnocentric encounter? Exploring the 'universalist' imperative of emotional/affectual geographies', Area 38, no. 2 (2006), pp. 213-217. 